The Australian species has 14 ribs, while the New-Zealand species has only 12 , of which the first one is broad and flat, and has, like the second, third, fourth, fifth, and sixth, two articulating surfaces; whilst, according to MacLeay, the Australian species has only one articulating surface on the first rib. The second rib exhibits a considerable breadth, whilst the succeeding ones become gradually narrower. The last six ribs, which assume a rounded shape, possess only one articulating surface.

Even supposing the minor difference in the form of the skull to be due to sex, the number, arrangement, and form of the vertebræ and ribs would prove the distinct specific character of the NewZealand specimen.

The contents of the stomach consisted of a dark slimy matter, without any beaks of Cephalopods as found in Berardius Arnuxi.

There is only a single valve covering the blowholes, the slit being 2 inches long, of which $1 \frac{1}{2}$ inch lies on the left and $\frac{1}{2}$ inch on the right side of the top of the head. The skin surrounding the valve is raised in a lunate form rather conspicuously on the left side, open posteriorly. The left side of the valve is far more developed and stronger than the right one.

The skeleton will be figured in the forthcoming volume of the 'Transactions of the New-Zealand Institute,' t. xv.

\title{
On a new Genus of Asellidæ. By Oscar Harger.
}

The presence of mandibular palpi has been hitherto regarded as a character of the family of Asellida, and is thus given by Dana (U. S. Exploring Expedition, Crustacea, p. 714), and by Bate and Westwood, in their late work on British Sessile-eyed Crustacea, vol. ii. p. 313. This organ is present and well developed in Jora copiosa, Asellodes alta, and Limnoria lignorum, marine species of this family found on the coast of New England. It has been carefully figured by G. O. Sars (Hist. Nat. des Crustacés d'eau douce de Norvège, $1^{\mathrm{e}}$ livr. pl. viii.) for Asellus aquaticus, and occurs in A. communis, Say, as well developed as in the European species; but in A. tenax, Smith, from Lake Superior, it is wanting. This species seems to be in all other respects closely related to the genus Asellus, differing from other species of that genus by characters of specific value only. The most noticeable of these differences are the following:- - the antennulæ have the third segment of the peduncle small, short, and similar to those of the flagellum; the ocelli are numerous, as in A. communis; the appendages of the first abdominal segment in the females are sub-quadrant-shaped, meeting each other along the median line, much as in A. communis, instead of subcircular and overlapping as in A. aquaticus. The caudal stylets resemble those of $A$. aquaticus, as do also the feet and the mouth-parts, except in the absence of the mandibular palpi; and on this character I propose for the species the new generic name of Asellopsis.-Silliman's American Journal, June 1874. 


\section{$2 \mathrm{BHL}$ Biodiversity Heritage Library}

Harger, Oscar. 1874. "On a new genus of Asellidæ." The Annals and magazine of natural history; zoology, botany, and geology 14, 168-168. https://doi.org/10.1080/00222937408680949.

View This Item Online: https://www.biodiversitylibrary.org/item/63340

DOI: https://doi.org/10.1080/00222937408680949

Permalink: https://www.biodiversitylibrary.org/partpdf/58741

\section{Holding Institution}

University of Toronto - Gerstein Science Information Centre

\section{Sponsored by}

University of Toronto

\section{Copyright \& Reuse}

Copyright Status: NOT_IN_COPYRIGHT

This document was created from content at the Biodiversity Heritage Library, the world's largest open access digital library for biodiversity literature and archives. Visit BHL at https://www.biodiversitylibrary.org. 